\title{
INTEGRATING SCIENTIFIC WITH HISTOLOGIC AND EMBRYOLOGIC COMPETENCIES
}

\author{
INTEGRANDO COMPETENCIAS CIENTÍFICAS CON HISTOLÓGICAS \\ Y EMBRIOLÓGICAS
}

\author{
D'Ottavio Cattani, Alberto Enrique 1,2 \\ ${ }^{1}$ Histology and Embryology Department, Faculty of Medical Sciences, National Rosario University, \\ Rosario, Argentina \\ 2 Research Council, National Rosario University, Rosario, Argentina \\ Recibido: 25/01/2021 | Revisado: 07/03/2021 | Aceptado: 08/05/2021 \\ DOI: 10.15568/am.2021.813.or01 \\ Actual Med. 2021; 106(813): 152-156
}

\section{Original}

\begin{abstract}
Objective: Given the relevance of scientific training in undergraduates whatever their future professional practice and viewing that consistent bibliographic usually limit scientific training to a component of the medical curriculum, this approach intends to go a step further seizing each discipline of the medical curriculum for developing progressively scientific competencies. In this context, a strategy, integrating scientific and disciplinary competencies (in this case, Histology and Embryology), is presented

Material and Method: The strategy was applied for fifteen years to $2000 \pm 500$ students per year while they were studying Histology and Embryology, one of the first-year disciplines. It included planning steps carried out by Ph.D. professors as well as the implementing and evaluating ones in charge of these professors and properly trained teachers

Results: Averages of percentages of enrolled students who did not start the course, who dropped out before being able to take the final disciplinary evaluation, who could take it and who were promoted to the second year during fifteen years are registered. Likewise, an average of $80 \%$ of them satisfied with this strategy and the positive impact on the corresponding competencies of Biology, another first-year discipline, are also recorded. Conclusions: This strategy, implemented between 1986 and 2001, proved viable and fruitfully relevant until a curricular transformation limited its continuation without generating its equivalent replacement. Beyond the elapsed time since then and the reasons hindering its full accomplishment, this long-standing approach is rescued so that it may eventually be considered and improved by those who may value it profitably for their curricula.
\end{abstract}

\section{RESUMEN}

Objetivo: Dada la relevancia de la formación científica en los estudiantes de grado, cualquiera sea su futura práctica profesional, y dado que consistentes reportes bibliográficos limitan usualmente el entrenamiento científico a una parte del currículo, este enfoque intenta ir un paso más allá aprovechando cada disciplina del currículo médico para desarrollar progresivamente competencias científicas. En este marco, es presentada una estrategia que integra tales competencias con las histológico-embriológicas.

Material y Método: Dicha estrategia fue implementada durante quince años a $2000 \pm 500$ alumnos por año mientras cursaban Histología y Embriología, una de las disciplinas de primer año, e incluyó etapas planificadoras a cargo de Profesores Doctores, así como otras, implementadoras y evaluadoras, a cargo de éstos y de docentes debidamente entrenados.

Resultados: Son registrados los promedios de porcentajes de alumnos inscriptos que no iniciaron el curso, que desertaron antes de estar habilitados para el examen final disciplinar, que lo cumplieron y que se promovieron a segundo año a lo largo de ese periodo. Asimismo, se da cuenta del promedio de satisfacción del alumnado con esta estrategia (80\%) y de su impacto positivo sobre las correspondientes competencias en Biología, otra disciplina de primer año

Conclusiones: Esta estrategia, implementada entre 1986 y 2001, se mostró viable y fructuosamente relevante hasta que una transformación curricular limitó su prosecución sin generar su equivalente reemplazo. Más allá del tiempo transcurrido desde entonces y de las razones que dificultaron su pleno cumplimiento, se rescata este perdurable enfoque para que eventualmente sea considerado y mejorado por quienes lo valoren de manera provechosa para sus currículos.

Correspondencia

Alberto Enrique D'Ottavio Cattani

Entre Ríos · 1214 2nd Floor, Rosario, Argentina

E-mail: aedottavio@hotmail.com
Keywords: Medicine; Integration; Science; Histology; Embryology; Competencies

Palabras clave: Medicina; Integración; Ciencia: Histología; Embriología; Competencias. 


\section{INTRODUCTION}

Medicine offers several ways of professional practice. Beyond the usually esteemed medical activity (i.e., healthcare medicine), scientific research, university teaching, institutional management, and public health are also worth mentioning.

Whatever their future professional practice, scientific training is extremely relevant for undergraduates. This is reflected in consistent bibliographic reports on implementing research challenges,

However, those reports - even some from our own usually limit scientific training to a part of the medical curriculum and separately of any medical discipline $(1-6)$.

Consequently, this approach intends to go further seizing each discipline for raising scientific thought from the beginning to the end of the medical curriculum. Hence, students may build progressively, piece by piece, a solid and useful scientific construct from the first to the last discipline of their career.

In this context, this paper presents a long-standing strategy, integrating scientific and disciplinary competencies (in this case, Histology and Embryology).

\section{MATERIAL AND METHODS}

This integrated strategy was applied for fifteen years to $2000 \pm 500$ students per year while they were studying Histology and Embryology, one of the first-year disciplines. It was part of the progressive scientific curricular training registered in Table 1 which provides an orienting outline to clarify the related contributions coming from Histology and Embryology.

The process included planning, implementing and evaluating steps.

The planning step, carried out by Ph.D. professors before learning meetings, required:

(A) Establishing the scientific competencies to be trained integrated with the histological and/or embryological ones. Among them: proficiency in English along with novel information and communication techniques (ICT) (actually, a prerequisite), science (origin, evolution and characteristics), types of scientific reasoning: deduction, incomplete induction, abduction, and analogy, null and alternative hypothesis, corroboration and refutation of hypotheses, critical thinking (confrontation of pros and cons) and quantitative and qualitative methods; (B) Design of histological and/or embryological lectures and practical meetings

\begin{tabular}{|c|c|}
\hline & Increasing scientific curricular training \\
\hline $\begin{array}{l}1^{\text {st }} \\
\text { year }\end{array}$ & $\begin{array}{l}\text { Former scientific contributions from Anatomy, Histology and Embryology, Biology and Medicine } \\
\text { and Society }\end{array}$ \\
\hline $\begin{array}{l}2^{\text {nd }} \\
\text { year }\end{array}$ & $\begin{array}{l}\text { Statistical techniques - Graphic interpretations } \\
\text { Optional joining to preexisting research teams for initial training }\end{array}$ \\
\hline $\begin{array}{l}3^{\text {rd }} \\
\text { year }\end{array}$ & $\begin{array}{l}\text { Critical Reading of scientific articles Level } 1 \text { (3) } \\
\text { Optional joining to preexisting research teams for initial or advanced training }\end{array}$ \\
\hline $\begin{array}{l}4^{\text {th }} \text {. } \\
\text { year }\end{array}$ & $\begin{array}{l}\text { Critical Reading of scientific articles Level } 2(3) \\
\text { Optional joining to preexisting research teams for initial or advanced training }\end{array}$ \\
\hline $\begin{array}{l}5^{\text {th }} \\
\text { year }\end{array}$ & $\begin{array}{l}\text { Trained Critical Reading of scientific articles } \\
\text { Optional joining to preexisting research teams for initial or advanced training }\end{array}$ \\
\hline $\begin{array}{l}6^{\text {th }} \text {. } \\
\text { year }\end{array}$ & $\begin{array}{l}\text { Trained Critical Reading of scientific articles } \\
\text { Optional joining to preexisting research teams for initial training }\end{array}$ \\
\hline
\end{tabular}

Table 1. Curricular outline until 2001 included 
including the abovementioned scientific requirements and/or simultaneous scientific-proceeding challenges like (a) discerning between characterization and definition, description and explanation, beliefs, opinion (doxa) and scientific knowledge (episteme), suspended (doubt) or absent judgment (ignorance) and certainty; (b) making bibliographic updates through critical searches on well-qualified sites; (c) extracting the core from publication summaries; (d) registering references according to APA, Vancouver, Harvard or other publication standards; (e) two-dimensional interpretation of figures and three-dimensional bodies, and (e) evaluating the accurateness of methodological procedures, among the main ones $(7,8)$.

In this regard, a general example for theoretical and/ or practical meetings and particular problem-solving examples for practical meetings, both linked to histological and/or embryological issues, allow understanding how components of items $\mathrm{A}$ and $\mathrm{B}$ may be transferred from theory to practice.

General example for theoretical and/or practical meetings linked to histological and/or embryological issues

The study of microscopes, histological techniques, cells, tissues and organic systems as well as the embryologic development, differentiation and maturation allow facing their discoveries and temporary modifications. In this regard, appreciation of where knowledge comes from and how it diachronically changes reveal why science is dynamic and provisional. Besides, it allows complementing other science characteristics and applying timely all the aforementioned concepts.

Particular problem-solving example linked with histological issues for practical meetings

As a result of a car accident, a 38-year-old female, blood group AB Factor Rh-negative, suffered multiple injuries. Without losing her consciousness but dizzy, she was quickly transferred to a hospital. There, she was transfused with $500 \mathrm{cc}$. of blood after revealing: blood pressure: 90/40 mmHg; pulse: 145 / min; hematocrit: $28 \%$ and axillary temperature: $36.5^{\circ} \mathrm{C}$. On her right leg, she evidenced superficial and deep burns of the first and second degree, pain in some of them, and blisters. On the left leg, an exposed fracture and a bleeding vascular lesion were perceptible. The fracture and the vascular lesion were surgically repaired, and a cast was placed on the left leg, immobilizing the knee and ankle joints for 30 days. Burns were treated according to their grade whereas gamma globulin and tetanus vaccine were injected. The patient remained in hospital. Later, one of the burns was contaminated by hospital germs leading to an infection with fever and lymphadenopathy for which antibiotics were administered. The clinical condition improved favorably. Other non-infected burn did not heal satisfactorily, leading to a skin autotransplantation. The patient evolved without complications or sequelae of her burns and frac- ture. When removing the cast, the left leg revealed less volume and less strength than the right one with some movement difficulty of the ankle joint. Rehabilitation was indicated (9).

Analyze the presented problem, pointing out to its histophysiological contents, and relate the symptoms and signs with the histological structures and functions.

What kind of scientific reasoning is employed in this problem?

Are there any descriptions and/or explanations about it?

What bibliography did you searched for? And what was its year of publication?

Establish some hypotheses that may guide the adopted decisions.

On what scientific basis the described decision is made?

The method followed is more quantitative than qualitative or vice versa?

How do you imagine the same situation during the XIXth century or at the beginning of XXth one?

When did antibiotics appear, and which was the first one of them? What is serendipity?

\section{Particular problem-solving example linked with em- bryological issues for practical meetings}

A forty-two year old woman consults to her gynecologist about the possibility of having a baby with Down syndrome

Analyze why an embryo-fetus may develop Down syndrome

Relate it con cytological contents

Establish the most frequent embryological problems accompanying this syndrome

What additional examinations the gynecologist indicates for corroborating or refusing his own hypothesis?

Is the woman's conjecturing a hypothesis? If so, why

What kind of scientific reasoning is employed in this problem?

The method followed is more quantitative than qualitative or vice versa?

The implementing step was mainly carried out by the referred professors during their two-hour theoretical 
lectures and complemented, particularly with problem solving, by professionally trained teachers during their two-hour practical meetings (two per week during 30 weeks per year in both cases)

From an integrated standpoint, both implementations demanded: (a) motivating, didactic, valid, reliable, and up-to-date knowledge transmission; (b) fostering attitudes, habits, and values, advocated by examples and liable to emulation, and (c) knowledge application and development of cognitive, communication, and motor skills through problem-solving.

Finally, the evaluating step was carried out during the formal six periodic evaluations and the final one through oral and/or written tests in charge of the abovementioned Ph.D. professors and trained teachers.

Furthermore, a complementary interaction was performed with Biology, another first-year discipline including Methods in Scientific Research among its activities, for establishing the eventual positive impact of the Histology and Embryology strategy.

Table 2 synthesizes steps, method and responsible of the strategy. evaluation while $55 \pm 5 \%$ of those students, who completed the course in good terms, could take this kind of examination. In this regard, $75 \pm 5 \%$ of the students were usually promoted to the second year.

In this framework, this strategy, combining the discipline with the first stages of scientific thought, turned out to be satisfactory to an average of $80 \%$ of them according to a brief, anonymous and voluntary poll carried out immediately after that examination.

Furthermore, throughout its application, Biology reported in parallel a positive impact on its corresponding competencies.

\section{DISCUSSION}

This strategy, implemented between 1986 and 2001 when a curricular transformation changed the abovementioned approach, showed to be feasible and fruitfully relevant.

In the new curriculum, Histology, Embryology, and other first and second-year disciplines became

\begin{tabular}{|c|l|l|}
\hline STEPS & METHOD & RESPONSIBLE \\
\hline Planning & $\begin{array}{l}\text { Scientific competencies to be trained } \\
\text { integrated with the histological and/or } \\
\text { embryological ones } \\
\text { Design of histological and/or } \\
\text { embryological lectures and practical } \\
\text { meetings according to A }\end{array}$ & $\begin{array}{l}\text { Ph.D. professors before } \\
\text { learning meetings }\end{array}$ \\
\hline Implementation & $\begin{array}{l}\text { Two-hour theoretical lectures } \\
\text { Two-hour practical meetings with } \\
\text { problem-solving challenges } \\
\text { (Two per week during 30 weeks per year } \\
\text { in both cases) }\end{array}$ & $\begin{array}{l}\text { Trained teachers } \\
\text { Ph.D. professors }\end{array}$ \\
\hline Evaluation & $\begin{array}{l}\text { Six periodic evaluations and a final one } \\
\text { employing oral and/or written tests } \\
\text { Complementary interaction with Biology, } \\
\text { another first-year discipline }\end{array}$ & $\begin{array}{l}\text { Ph.D. professors and trained } \\
\text { teachers }\end{array}$ \\
\hline
\end{tabular}

Table 2. Details of the strategy: steps, method and responsible for each one of them

\section{RESULTS}

For fifteen years, an average of $25 \%$ of the enrolled students $(2000 \pm 500$ per year) repetitively did not start the course. An average of $25 \%$ of the coursing ones dropped out before completing all the proposed chances for remaining able to take the final disciplinary interdisciplinary areas and scientific competencies were brought together in an instrumental one: Methodology of Scientific Research (10). Without being replaced by other equivalent process, both changes prevented the implementation of the strategy as formerly carried out evidencing that, sometimes, advances in many respects may produce regressions in certain others. 
To conclude, it is convenient to repeat that papers on this issue, though truly consistent, do not integrate scientific and disciplinary competencies throughout the medical curriculum, being usually focused on other scientific aspects or limiting scientific training to a part of the medical curriculum and separately of any medical discipline (1-6).

\section{CONCLUSION}

Beyond the elapsed time since then and the reasons hindering its full achievement, this long-standing approach is rescued from the past so that it may eventually be considered and improved by those who may value it partly or entirely successfully for their curricula.

To sum up, I am still utterly convinced that every discipline (and every curriculum) gives enhancing opportunities in this regard and that these opportunities cannot be disregarded.

\section{ACKNOWLEDGEMENTS}

The author deeply acknowledges his unforgettable friend Norberto David Bassan MD ( $\dagger$ ) for his invaluable collaboration in the original design. This design not only influenced most of our publications cited in the references, but it was fed back by them in an enriching circle.

Likewise, the author wishes also to thank the permanent, friendly, and fruitful help received from Professor Oscar Adelmo Bottasso MD, Ph.D, former Director of the Institute of Clinical and Experimental Immunology of Rosario (IDICER, CONICET-UNR), member of the Provincial and National Academy of Medicine and Distinguished Doctor and Master of Medicine of the city of Rosario (Rosario, Argentina).

\section{BIBLIOGRAPHIC REFERENCES}

1. Katkin W. The Boyer Commission Report and Its Impact on Undergraduate Research. New Dir Teach. Learn. 2003; 93: 19-38. DOI: 10.1002/tl.86.

2. Montenegro SM, Tarrés MC, D'Ottavio AE. Entrenamiento científico en el grado deficiencias médicas; descripción, análisis y crítica de una experiencia innovadora en Argentina. Rev Arg Educ Med. 2007; 1(1): 17-22

3. Hren D, Lukić IK, Marusić A, Vodopivec I, Vujaklija A, Hrabak $M$, et al. Teaching research methodology in medical schools: students' attitudes towards and knowledge about science. Med Educ. 2004; 38(1): 81-6. DOI:10.1111/j.13652923.2004.01735.x
4. Laidlaw A, Aiton J, Struthers J, Guild S. Developing research skills in medical students: AMEE guide no. 69. Med Teach. 2012; 34(9): 754-71. DOI: 10.3109/0142159X.2012.704438

5. Ratte A, Drees S, Schmidt-Ott T. The importance of scientific competencies in German medical curricula - the student perspective. BMC Med Educ. 2018; 18(1): 146. DOI: 10.1186/s12909-018-1257-4

6. Schultes MT, Aijaz M, Klug J, Fixsen DL. Competencies for implementation science: what trainees need to learn and where they learn it. Adv Health Sci Educ. 2021; 26: 19-35. DOI: 10.1007/s10459-020-09969-8

7. Tarrés MC, Montenegro SM, D'Ottavio AE, Garcia Sánchez E. Lectura crítica del artículo científico como estrategia para el aprendizaje del proceso de investigación. Rev Iberoamer. Educ. 2008; 45(6): 1-8. DOI: 10.35362/rie4562025

8. Gayol MC, Montenegro SM, Tarrés MC, D'Ottavio AE. Competencias investigativas. Su desarrollo en carreras del área de la salud. Uni-pluri/versidad. 2008; 8(2): 1-8

9. Bassan ND, D'Ottavio AE, Soldano ORF, Vinuesa MA. El Aprendizaje Basado en Problemas en una unidad temática de histología médica. Opinión de los alumnos sobre logros y grado de satisfacción. RECS. 2007; 4(2): 116-20.

10. Carrera LI, Tellez TE, D'Ottavio AE. Implementing a problem-based learning curriculum in an Argentinean medical school: implications for developing countries. Acad Med. 2003; 78(8): 798-801. DOI: 10.1097/00001888-20030800000010

\section{CONFLICT OF INTERESTS}

The author of this article declare that he has no conflict of interest with respect to what is stated in this work.

\section{Si desea citar nuestro artículo:}

D'Ottavio Cattani, Alberto Enrique. Integrating scientific with histologic and embryologic competencies. Actual Med. 2021; 106(813): 152-156. DOI: 10.15568/am.2021.813.or01 